\title{
Behavior Analysis of Corona Virus Disease (Covid-19) Transmission Prevention With Health Belief Model Approach
}

\author{
Juwita Sahputri ${ }^{1}$, Rizka Sofia ${ }^{1}$, Teuku Azhari ${ }^{2}$ \\ ${ }^{I}$ Medical Study Program, Faculty of Medicine, Malikussaleh University \\ ${ }^{2}$ Chemical Engineering Department, Faculty of Engineering, Malikussaleh University \\ *Corresponding Author: juwita.sahputri@unimal.ac.id
}

\begin{abstract}
Covid-19 is a global pandemic and the tally keep on going up all across the world. The high prevalence or incidence of Covid-19 cases is of course related to individual perceptions of the disease which will shape the practice of Covid-19 transmission preventingin accordance with recommendations. This study aims to determine the Covif-19 transmission prevention behavior among students of the Medical Study Program FK Unimal class of 2017 based on the Health Belief Model application. This research was a descriptive analytic study, using cross sectional method with a total sampling of 86 . The results of the study were presented as univkeepariate descriptive analysis and bivariate analysis using the chi square test. The results showed that $77 \%$ of respondents were female, $31 \%$ lived in green zone areas, $65.1 \%$ of respondents had Covid-19 prevention behavior in the fairly good category. Perceptions of vulnerability were mostly in the fairly good category with good enough behavior as many as 41 respondents (70.7\%), the most perceived severity was in the fairly good category with good enough behavior as many as 34 respondents (66.7\%). Fair category with good enough behavior, namely 52 respondents $(75.4 \%)$, the most perceived benefits in the fairly good category with good enough behavior were 30 respondents $(76.9 \%)$, perception cues to act obtained good perceptions with good enough behavior, namely 28 respondents $(59.6 \%)$ and the perception was quite good with good enough behavior were 28 respondents $(71.8 \%)$. The results of the bivariate analysis showed that perceived barrier factor had significant relationship with Covid-19 prevention behavior $(\mathrm{p}=0.000)$.
\end{abstract}

Keywords: Covid-19, Health Belief Model, Preventive Behavior

\section{INTRODUCTION}

Covid-19 has been widespread and the tally keeps on increasing. On January 30, 2020, the WHO Emergency Committee announced the incident as a pandemic [1].

Covid-19 also called as SARS-CoV-2 transmitted aggressively. Transmission occured viadroplet from cough or sneeze of carriers. So far only supportive and symptomatic therapy has been performed on Covid-19 patients. The high prevalence or incidence of Covid-19 cases is of course related to the practice of prevention of Covid-19 transmission in accordance with government recommendations [2]. Therefore, prevention and control of this pandemic can be carried out by observing health protocols and maintaining personal hygiene, such as washing hands regularly with soap and water, keeping a distance from each other, covering the mouth and nose when coughing and sneezing, and not touching the nose, mouth and eyes.

There are several factors that affect a person's health status. One of the factors that greatly affects the degree of health is behavior. A person's behavior is the most difficult determinant to overcome. Each person has a confidence assessment on the level of vulnerability and severity of each so that they make efforts to prevent a disease. Assessment of healthy action in an effort to prevent this disease can be done by using the Health Belief Model (HBM) which includes perceived susceptibility, perceived severity, perceived barriers, perceived benefits, and cues. to act (cue to action) so that the trust factor of someone who is the background in preventing Covid-19 is obtained [3] and Rosenstock (1974) in [4]. 


\section{RESEARCH METHODS}

This research is a descriptive analytic study with a cross sectional design which was conducted in the Medical Study Program of the Faculty of Medicine, University of Malikussaleh. The sampling technique used the total sampling technique, namely samples that met the inclusion and exclusion criteria, namely as many as 86 samples, namely students of the 2017 FK Unimal Medical Study Program.

The instrument used in this study was an online questionnaire with the concept of Health Belief Model via googleform. Measurement instruments utilized 4 steps Likert scale (values 1-4). Later the scoring were divided into three main categories: good: $76 \%-100 \%$, good enough: $75 \%-56 \%$ and less good: $<56 \%$. This instrument has been used to examine individual perceptions of HBM on the prevention of Covid-19 in Iran by Shahnazi (2020) et al and has been tested for reliability. The variables assessed were: 8 questions of covid-19 transmission prevention behavior, 3 questions of perceived susceptibility, 3 questions of perceived severity, 8 questions of perceived barriers, 2 questions of perceived benefits. , perception of cues to action (cues to action) 1 question. The data source in this study is primary data obtained from questionnaires filled out by students. The collected data were processed and analyzed in univariate and bivariate ways (with the chi square test, the level of significance $(\alpha)$ was 0.05 , the degree of confidence was $95 \%)$.

\section{RESULTS}

\subsection{Univariate Analysis}

The results showed that the number of respondents based on gender, with 20 (23\%) male, and $66(77 \%)$ female respondents. 24 (28\%) students were noted to life in the red zone, $18(21 \%)$ respondents life in yellow zone, $17(20 \%)$ life in yellow zone, and 27 (31\%) life in green zone.

\subsection{Bivariate Analysis}

Table 1 The Relationship between Perceptions of Vulnerability and Covid-19 Prevention Behavior

\begin{tabular}{|c|c|c|c|c|c|c|c|c|}
\hline \multirow{3}{*}{$\begin{array}{c}\text { Perceived } \\
\text { susceptibilit } \\
\text { y }\end{array}$} & \multicolumn{6}{|c|}{ Behavior Category } & \multirow{2}{*}{$\begin{array}{c}\text { Tot } \\
\text { al }\end{array}$} & \multirow{2}{*}{$\begin{array}{c}\text { p- } \\
\text { value }\end{array}$} \\
\hline & \multicolumn{2}{|c|}{ Good } & \multicolumn{2}{|c|}{$\begin{array}{c}\text { Pretty } \\
\text { good }\end{array}$} & \multicolumn{2}{|c|}{$\begin{array}{c}\text { Not } \\
\text { good }\end{array}$} & & \\
\hline & $\mathrm{f}$ & $\%$ & $\mathrm{f}$ & $\%$ & $\mathrm{f}$ & $\%$ & $\mathrm{f}$ & \\
\hline
\end{tabular}

\begin{tabular}{|c|c|c|c|c|c|c|c|c|}
\hline Good & 12 & 42.9 & 15 & $\begin{array}{c}53 . \\
6 \\
\end{array}$ & 1 & 3,6 & 28 & \multirow{4}{*}{$\begin{array}{c}0.13 \\
9\end{array}$} \\
\hline $\begin{array}{c}\text { Pretty } \\
\text { good }\end{array}$ & 17 & 29.3 & 41 & $\begin{array}{c}70 . \\
7 \\
\end{array}$ & 0 & 0 & 58 & \\
\hline Not good & 0 & 0 & 0 & 0 & 0 & 0 & 0 & \\
\hline Total & 29 & 33.7 & 56 & $\begin{array}{c}65 . \\
1\end{array}$ & 1 & 1,2 & 86 & \\
\hline
\end{tabular}

Source: Primary Data, 2020

The results showed that the perception of vulnerability was mostly good enough with as many as 41 respondents $(70.7 \%)$. Based on bivariate analysis with testchi square obtained a p-value of 0.139 . This indicated no relationship between perceived susceptibility of respondents with Covid19 prevention behavior among FK Unimal students class of 2017.

Table 2 The Relationship between Perceptions of Severity and Covid-19 Prevention Behavior

\begin{tabular}{|c|c|c|c|c|c|c|c|c|}
\hline \multirow{3}{*}{$\begin{array}{c}\text { Perceived } \\
\text { severity }\end{array}$} & \multicolumn{6}{|c|}{ Behavior Category } & \multirow{2}{*}{ Total } & \multirow{3}{*}{$\mathrm{p}$-value } \\
\hline & \multicolumn{2}{|c|}{ Good } & \multicolumn{2}{|c|}{$\begin{array}{l}\text { Pretty } \\
\text { good }\end{array}$} & \multicolumn{2}{|c|}{$\begin{array}{l}\text { Not } \\
\text { good }\end{array}$} & & \\
\hline & $\mathrm{f}$ & $\%$ & $\mathrm{f}$ & $\%$ & $\mathrm{f}$ & $\%$ & $\mathrm{f}$ & \\
\hline Good & 12 & 34.3 & 22 & 62.9 & 1 & 2.9 & 35 & \multirow{4}{*}{0.470} \\
\hline $\begin{array}{l}\text { Pretty } \\
\text { good }\end{array}$ & 17 & 33.3 & 34 & 66.7 & 0 & 0 & 51 & \\
\hline Not good & 0 & 0 & 0 & 0 & 0 & 0 & 0 & \\
\hline Total & 29 & 33.7 & 56 & 65.1 & 1 & 1,2 & 86 & \\
\hline
\end{tabular}

Source: Primary Data, 2020

Based on the bivariate analysis with the chi square test, it was found that the p-value was 0.470 , so it could be concluded that there was no relationship between perceived severity of respondents and the prevention behavior.

Table 3 The Relationship between Perceptions of Barriers and Behavior to Prevent Covid-19

\begin{tabular}{|c|c|c|c|c|c|c|c|c|}
\hline \multirow{3}{*}{$\begin{array}{c}\text { Perceived } \\
\text { barriers }\end{array}$} & \multicolumn{6}{|c|}{ Behavior Category } & \multirow{3}{*}{$\begin{array}{c}\text { To } \\
\text { tal } \\
\mathrm{f}\end{array}$} & \multirow{3}{*}{$\begin{array}{c}\text { p- } \\
\text { value }\end{array}$} \\
\hline & \multicolumn{2}{|c|}{ Good } & \multicolumn{2}{|c|}{$\begin{array}{l}\text { Pretty } \\
\text { good }\end{array}$} & \multicolumn{2}{|c|}{$\begin{array}{l}\text { Not } \\
\text { good }\end{array}$} & & \\
\hline & f & $\%$ & f & $\%$ & f & $\%$ & & \\
\hline Lots & 13 & 76.5 & 4 & 23.5 & 0 & 0 & 17 & 0,00 \\
\hline Enough & 16 & 23.2 & 52 & 75.4 & 1 & 1.4 & 69 & 0 \\
\hline Less & 0 & 0 & 0 & 0 & 0 & 0 & 0 & \\
\hline Total & 29 & 33.7 & 56 & 65.1 & 1 & 1,2 & 86 & \\
\hline
\end{tabular}

Source: Primary Data, 2020 
Table 4 The Relationship between Perceptions of Benefits and Covid-19 Prevention Behavior

\begin{tabular}{|c|c|c|c|c|c|c|c|c|}
\hline \multirow{3}{*}{$\begin{array}{c}\text { Perceive } \\
\text { d } \\
\text { benefits }\end{array}$} & \multicolumn{6}{|c|}{ Behavior Category } & \multirow{2}{*}{$\begin{array}{c}\text { Tota } \\
1\end{array}$} & \multirow{3}{*}{$\begin{array}{c}\mathrm{p}- \\
\text { value }\end{array}$} \\
\hline & \multicolumn{2}{|c|}{ Good } & \multicolumn{2}{|c|}{$\begin{array}{c}\text { Pretty } \\
\text { good }\end{array}$} & \multicolumn{2}{|c|}{$\begin{array}{l}\text { Not } \\
\text { good }\end{array}$} & & \\
\hline & $\mathrm{f}$ & $\%$ & $f$ & $\%$ & $\mathrm{f}$ & $\%$ & $\mathrm{~F}$ & \\
\hline Good & 19 & $\begin{array}{c}42 . \\
2\end{array}$ & 25 & $\begin{array}{c}55 . \\
6\end{array}$ & 1 & $\begin{array}{l}2, \\
2\end{array}$ & 45 & \\
\hline $\begin{array}{l}\text { Pretty } \\
\text { good }\end{array}$ & 9 & $\begin{array}{c}23 . \\
1\end{array}$ & 30 & $\begin{array}{c}76 . \\
9\end{array}$ & 0 & 0 & 49 & 0.300 \\
\hline Not good & 1 & 50 & 1 & 50 & 0 & 0 & 2 & \\
\hline Total & 29 & $\begin{array}{c}33 . \\
7\end{array}$ & 56 & $\begin{array}{c}65 . \\
1\end{array}$ & 1 & $\begin{array}{l}1, \\
2\end{array}$ & 86 & \\
\hline
\end{tabular}

Source: Primary Data, 2020

The results showed that the most perceived benefits were in the fairly good category with good enough behavior were 30 respondents (76.9\%). Based on the bivariate analysis with the chi square test, it was obtained a p-value of 0.300 , so it can be concluded that there is no relationship between perceived benefits of respondents and the prevention behavior of Covid-19 among FK Unimal students class of 2017.

Table 5 The Relationship between Perceptions of Action and Behavior to Prevent Covid-19

\begin{tabular}{|c|c|c|c|c|c|c|c|c|}
\hline \multirow{3}{*}{$\begin{array}{c}\text { Perception } \\
\text { of cues to } \\
\text { action } \\
\text { (cue to } \\
\text { action) }\end{array}$} & \multicolumn{6}{|c|}{ Behavior Category } & \multirow[b]{2}{*}{ Total } & \multirow[b]{2}{*}{ p-value } \\
\hline & \multicolumn{2}{|c|}{ Good } & \multicolumn{2}{|c|}{$\begin{array}{l}\text { Pretty } \\
\text { good }\end{array}$} & \multicolumn{2}{|c|}{$\begin{array}{l}\text { Not } \\
\text { good }\end{array}$} & & \\
\hline & $f$ & $\%$ & $\mathrm{f}$ & $\%$ & $\mathrm{~F}$ & $\%$ & $\mathrm{~F}$ & \multirow{5}{*}{0.375} \\
\hline Good & 18 & 38.3 & 28 & 59.6 & 1 & 2.1 & 47 & \\
\hline $\begin{array}{l}\text { Pretty } \\
\text { good }\end{array}$ & 11 & 28.2 & 28 & 71.8 & 0 & 0 & 39 & \\
\hline Not good & 0 & 0 & 0 & 0 & 0 & 0 & 0 & \\
\hline Total & 29 & 33.7 & 56 & 65.1 & 1 & 1,2 & 86 & \\
\hline
\end{tabular}

Source: Primary Data, 2020

The results showed that 28 respondents (59.6\%) had good perceptions with good enough behavior and 28 respondents (71.8\%) who had good enough perceptions with good enough behavior. The p-value was 0.375 so it could be concluded that there was no relationship between the respondent's cue to action and the Covid-19 prevention behavior in FK Unimal students class of 2017.

\section{DISCUSSION}

\subsection{Preventive Behavior Against Covid-19}

The frequency distribution of Covid-19 prevention behaviorcould be seen as follows. 29 (33.7\%) good category, $56(65.1 \%)$ good enough, and
1 respondent (1.2\%) in poor category. From the results of the study it can be seen that $65.1 \%$ of students have fairly good behavior in preventing Covid-19 transmission by implementing health protocol for Covid 19 prevention measures such as cough and sneezing ethics, maintaining a distance of at least 1 meter with other people, not shaking hands, not leaving the house unless absolutely necessary, washing hands regularly with soap and water for 20 seconds before entering the house and do not touch anything beforehand, not touchingeyes, nose and mouth with hands [2].

Implementing healthy behaviors in preventing Covid-19 is a wise step to ward off disease, but in practice, implementing simple health behaviors is not always easy to do, especially for respondents who are not used to it, lack of knowledge and at least awareness of healthy lifestyle behavior. Everyone must be willing and able to make behavior changes so that they can prevent the transmission of Covid-19. Currently more and more people are confirmed positive for Covid-19 without symptoms, so healthy behavior is an important preventive measure. Efforts that can be made to deal with Covid-19 are physical distancing, diligently washing hands with soap and using masks when leaving the house [5].

\subsection{The Relationship between Perceptions and Prevention Behavior}

Individuals are willing to take precautionary measures if they feel that they are seriously affected by Covid-19 infection (perceived severity), feel that they are vulnerable or are likely to be infected (perceived susceptibility). In addition, the ease and obstacles as well as the benefits obtained from taking preventive action (perceived benefits) are reasons for individuals to decide on preventive action. In this study, the perception of vulnerability and the perception of severity did not have a significant relationship with the behavior to prevent Covid-19 transmission. In general, the perception of vulnerability and the perception of severity should be important variables to motivate and encourage individuals to take preventive action. So that individuals must feel themselves vulnerable to disease and understand the dangers of covid disease. These results are in line with research conducted in Iran (2020) which also did not have a significant 
relationship between perceived vulnerability and perceived severity with Covid-19 disease prevention behavior. Different results were shown by the study of Qian et al. In China which showed that the level of susceptibility and disease severity were important predictors in increasing the prevention behavior of Covid-19 disease in China [2], [6]

According to Rosenstock in the book Health Behavior and Health Education, which states a person's beliefs about vulnerability and seriousness / severity have an influence in taking action. The level of severity is perceived starting from the extent to which a person's illness will cause discomfort to cause death. The severity of the disease that is felt causes the individual to believe that the consequences of the severity of the disease are a threat to his life . Perceptions of perceived vulnerability / severity will affect a person's intention to behave, belief in the existence of a threat or someone's vulnerability to a disease, it will motivate someone to take an action or behavior to prevent disease transmission [7].

Research in Egypt shows that there is a positive link between perceived vulnerability and covid-19 prevention behavior due to the continuous increase in the number of reported cases of infection, making respondents in the study feel more likely to have contracted the disease. Individuals will do better to increase the perception of the benefits of disease prevention such as using personal protective equipment such as masks, washing hands regularly, thereby increasing motivation to follow disease prevention measures [8].

The formation of benefit perceptions occurs based on a person's opinion about the use value of a new behavior or action that can reduce the risk of disease. Convincing the importance of perceived benefits is more effective in motivating individuals to practice disease prevention behavior than simply exposing the risks they get if they don't practice preventive behavior [8]. Washing hands with soap according to WHO is the right way according to health, because soap can kill germs or viruses that stick to the hands. So the simplest effort to uphold the pillars of a healthy life is to like to wash your hands. This effort that is considered trivial turns out to be able to make an important contribution to efforts to prevent Covid-19 [9].

The perceived benefits must be greater than the perceived barriers for behavior change to occur.
The perceived barrier is the perception of everything that becomes a barrier to implementing and adopting new behaviors. Perceived barriers to taking action include perceived discomfort (having to wear a mask when doing activities outside the home, maintaining a distance of \pm 1 meter from other individuals, restrictions on activities outside the home), costs (buying a mask or anti-septic gel), danger (for example, effects side of the medical procedure) and discomfort (eg, pain, emotional disturbance) involved in the behavior. In this study, the main obstacles felt were having to use a mask when doing activities outside the home, maintaining a distance of \pm 1 meter from other individuals [10].

The level of compliance with covid prevention behavior will increase by reducing perceived barriers. The perception of barriers is very important, because excessive barriers will prevent the desired health behavior from arising. Respondents are still not very enthusiastic because they still need to adapt to implement health protocols as part of carrying out daily activities [2].

Cues to action can come from internal or external factors such as information from magazines, newspapers, television, the internet and health workers. The amount of information obtained regarding the number of Covid-19 cases, the death rate, the transmission process and others will encourage and motivate someone to avoid the disease by implementing health protocols in their daily activities. The media has a very important role in conveying information and contributing to increasing one's awareness of risks, providing information about the effects of a risky behavior carried out and the benefits or benefits obtained by adopting healthy living behaviors. Cues to action are one of the triggering factors to decide whether to accept or reject alternative preventive measures. If someone has the motivating cues to act well, it is likely that they will take preventive action [10], [11]. Cues to act in this study are in the form of information obtained by respondents via television, radio, social media and other electronic media regarding Covid19, which greatly helps respondents to get information about Covid-19 [11].

\section{CONCLUSION}

The conclusions obtained in this study are as follows: 
1. The perception of susceptibility (perceived susceptibility) is more in the quite good category as many as 58 respondents $(67.4 \%)$, the perceived severity category is quite good 51 respondents $(59.3 \%)$, the perceived barriers are quite good category For 69 respondents $(80.2 \%)$, the perceived benefits obtained in good categories were 45 respondents $(52.3 \%)$

\section{REFERENCES}

[1] H. A. Rothan and S. N. Byrareddy, "The epidemeology and pathogensis of coronavirus (Covid-19) outbreak," $J$. Autoimmun., vol. 109, no. January, pp. $1-4,2020$.

[2] H. Shahnazi, M. Ahmadi-Livani, B. Pahlavanzadeh, A. Rajabi, M. S. Hamrah, and A. Charkazi, "Assessing Preventive Health Behaviors from COVID-19 Based on the Health Belief Model (HBM) among People in Golestan Province: A Cross-Sectional Study in Northern Iran," pp. 1-19, 2020, doi: 10.21203/rs.3.rs-24871/v1.

[3] Z. Obella and N. Adliyani, "Perubahan Perilaku Dan Konsep Diri Remaja Yang Sulit Bergaul Setelah Menjalani Pelatihan Keterampilan Sosial," $J$. Psikol. UGM, vol. 23, no. 1, pp. 13-20, 2016, doi: 10.22146/jpsi.10037.

[4] K. Glanz, B. k. Rimer, and K. Viswanath, Health Behavior and Health Education: Theory, Research, and Practice, 4th ed. Jossey-Bass, 2002.

[5] KemenkesRI, "Keputusan Menteri Kesehatan Republik Indonesia Nomor HK.01.07/MenKes/413/2020 Tentang Pedoman Pencegahan dan Pengendalian Corona Virus Disease 2019 (Covid-19)," MenKes/413/2020, vol. 2019, pp. 1-207, 2020.

[6] Y. Qian, Mengcen; Wu, Qianhui;Wu, Peng; Hou Zhiyuan; Liang, "Psychological responses, behavioral changes and public perceptions during the early phase of the COVID-19 and the perception of cues to action (cue to action) was obtained in good categories as many as 47 respondents $(54.7 \%)$.

2. There is a relationship between perceived barriers and Covid-19 prevention behavior with a p-value of $0.000(p<\alpha=0.005)$

outbreak in China: a population based cross-sectional survey," medRxiv, pp. 1$13,2020$.

[7] V. K. Glanz Karen, Rimer K. barbara, Health Behavior: Theory, Research, and Practice, 5th ed. Jossey-Bass, 2015.

[8] A. M. Barakat and Z. A. Kasemy, "Preventive health behaviours during coronavirus disease 2019 pandemic based on health belief model among Egyptians," Middle East Curr. Psychiatry, vol. 27, no. 1, 2020, doi: 10.1186/s43045-020-00051-y.

[9] Ibrahim, Kamaluddin, Mas'ad, M. AM, J. Gani, and A. Abd, "Bencana Virus Corona Melalui Sosialisasi Pada Anak Usia Dini," J. Pengabdi. Masy. Berkemajuan, vol. 3, no. 2, pp. 191-195, 2020.

[10] R. Jose, M. Narendran, A. Bindu, N. Beevi, M. L, and P. V. Benny, "Public perception and preparedness for the pandemic COVID 19: A Health Belief Model approach," Clin. Epidemiol. Glob. Heal., no. June, pp. 1-6, 2020, doi: 10.1016/j.cegh.2020.06.009.

[11] Z. V. Sakinah, "Aplikasi Health Belief Model Dalam Menganalisis Perilaku Penggunaan Kacamata Pelindung," $J$. PROMKES, vol. 5, no. 1, p. 115, 2018, doi: 10.20473/jpk.v5.i1.2017.115-128. 